\title{
Erratum
}

\section{Transcription initiation site of a NADP-specific glutamate dehydrogenase gene and potential use of its promoter region to express foreign genes in ammonium-cultured Chlorella sorokiniana cells **}

Philip W. Miller, Brenda L. Russell \& Robert R. Schmidt**

Department of Microbiology and Cell Science, University of Florida, Gainesville, FL 32611-0330, USA

( ${ }^{* *}$ Author for correspondence)

Journal of Applied Phycology Vol. 6, No. 2, pp. 211-223, 1994.

Due to an unfortunate technical error at the printers, Fig. 3 on p. 220 of the above issue was incorrect. Overleaf we present the correct figure.

** Florida Agriculture Experiment Station Serial No. R-03351. 


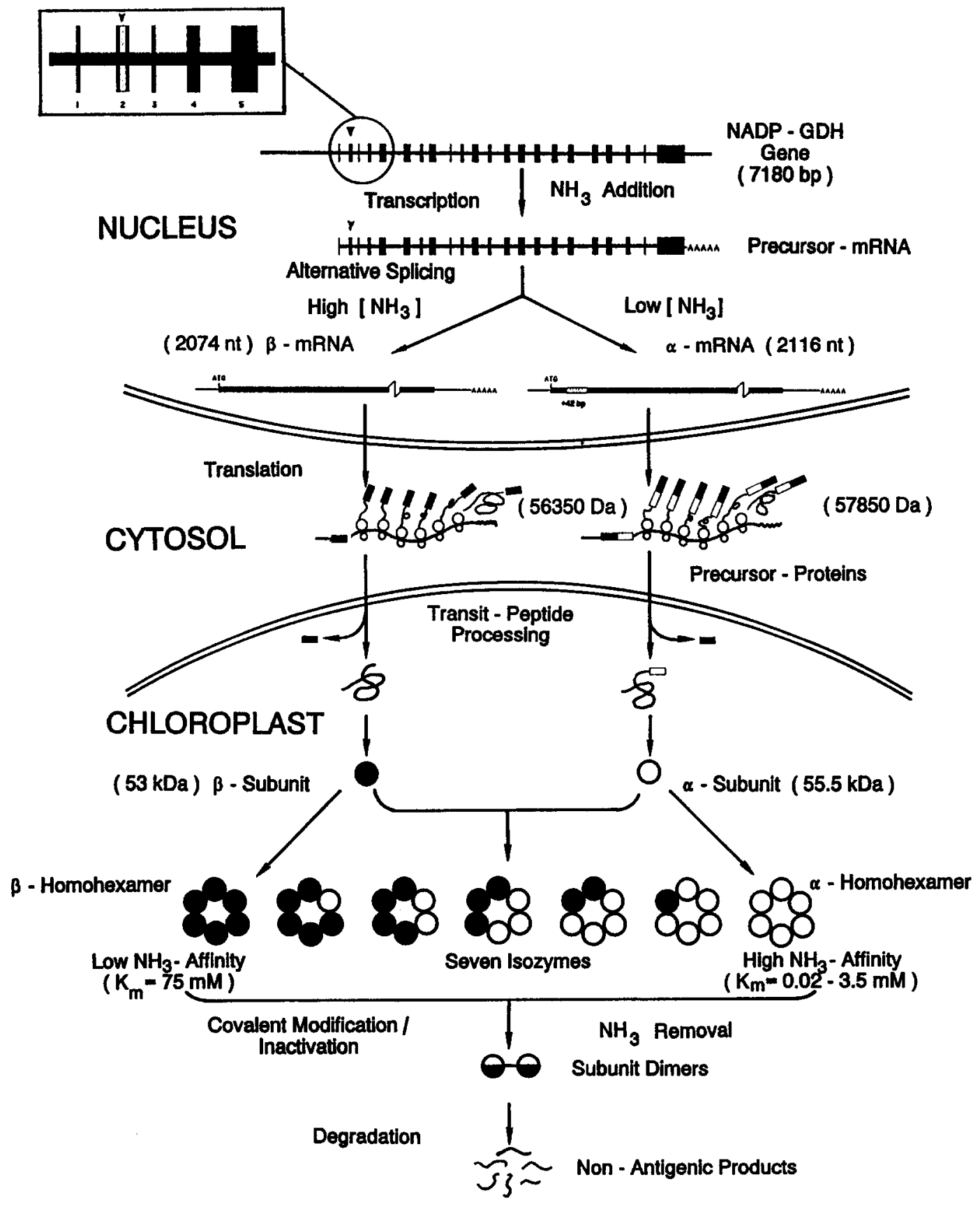

Journal of Applied Phycology, Vol. 6, No. 2, p. 220, Fig. 3 (April 1994).. 